\title{
Preliminary Gravity and Magnetic Data of the Lake Pillsbury Region, Northern Coast Ranges, California
}

By V.E. Langenheim, R.C. Jachens, R.L. Morin, and C.A. McCabe

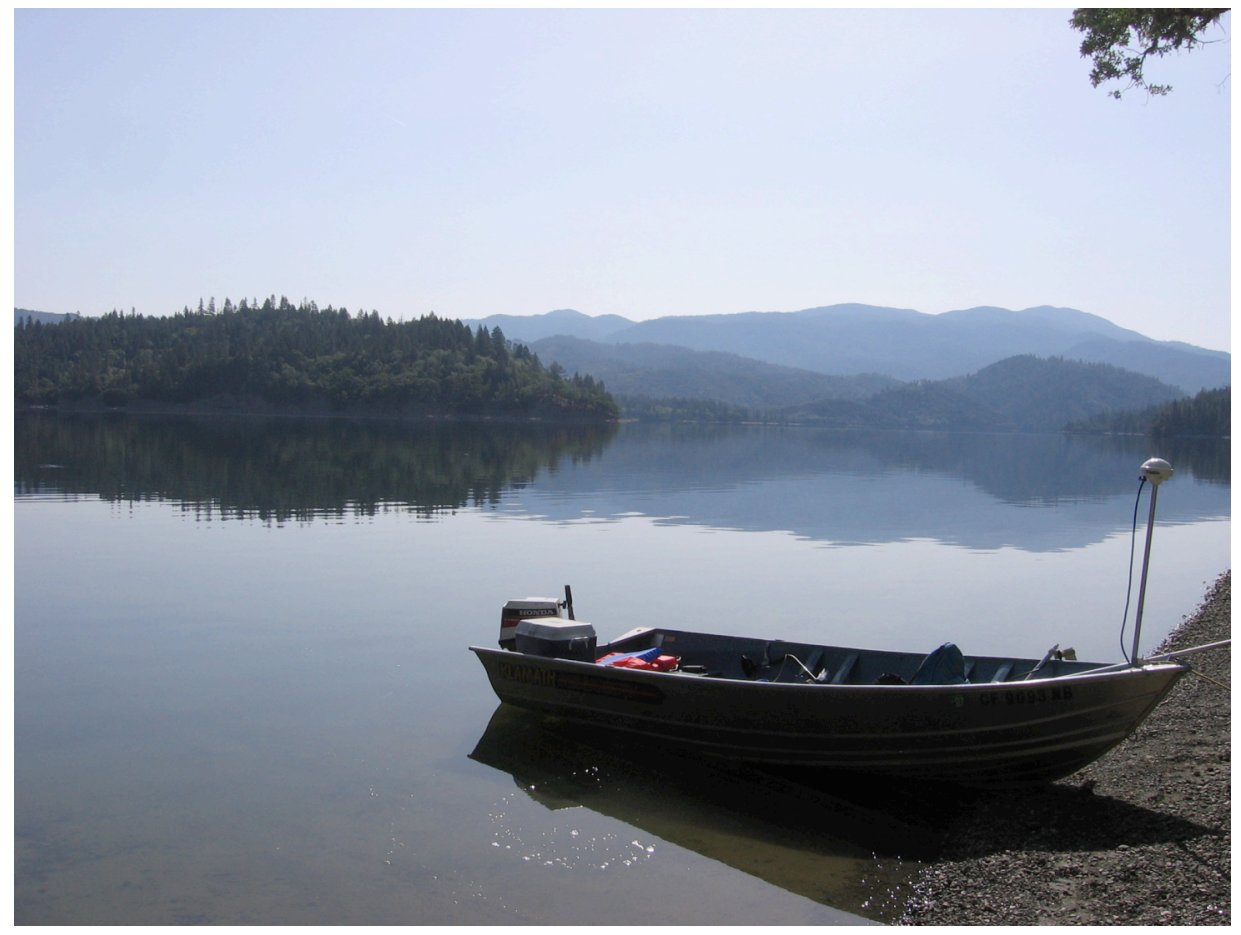

Open-File Report 2007-1368

U.S. Department of the Interior

U.S. Geological Survey

U.S. Department of the Interior 


\section{U.S. Department of the Interior \\ DIRK KEMPTHORNE, Secretary}

\section{U.S. Geological Survey \\ Mark D. Myers, Director}

U.S. Geological Survey, Reston, Virginia 2007

For product and ordering information:

World Wide Web: http://www.usgs.gov/pubprod

Telephone: 1-888-ASK-USGS

For more information on the USGS - the Federal source for science about the Earth, its natural and living resources, natural hazards, and the environment: World Wide Web: http://www.usgs.gov

Telephone: 1-888-ASK-USGS

Suggested citation:

Langenheim, V.E., Jachens, R.C., Morin, R.L., and McCabe, C.A., 2007, Preliminary gravity and magnetic data of the Lake Pillsbury region, northern Coast Ranges, California: U.S. Geological Survey Open-File Report 2007-1368 [http://pubs.usgs.gov/of/2007/1368/].

Any use of trade, product, or firm names is for descriptive purposes only and does not imply endorsement by the U.S. Government.

Although this report is in the public domain, permission must be secured from the individual copyright owners to reproduce any copyrighted material contained within this report. 


\section{TABLE OF CONTENTS}

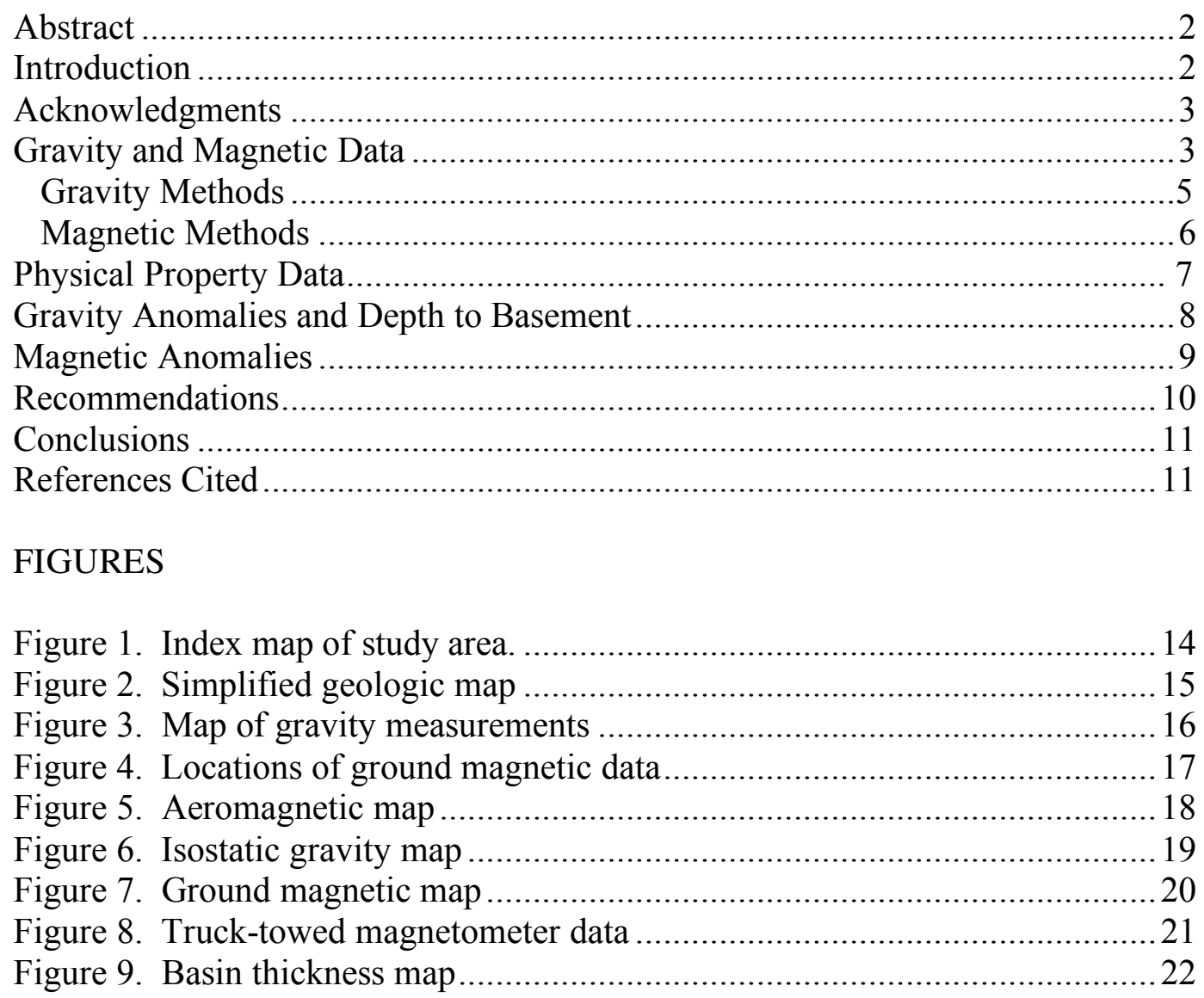

\section{TABLES}

Table 1. Aeromagnetic survey specifications.....................................................

Table 2. Density and magnetic susceptibility data. ............................................ 7 


\section{Abstract}

The Lake Pillsbury region is transected by the Bartlett Springs Fault zone, one of the main strike-slip faults of the San Andreas system north of San Francisco Bay, California. Gravity and magnetic data were collected to help characterize the geometry and offset of the fault zone as well as determine the geometry of the Gravelly Valley pull-apart basin and Potter Valley, an alluvial intermontane basin southwest of Lake Pillsbury. The Bartlett Springs fault zone lies at the base of a significant gravity gradient. Superposed on the gradient is a small gravity low centered over Lake Pillsbury and Gravelly Valley. Another small gravity low coincides with Potter Valley. Inversion of gravity data for basin thickness indicates a maximum thickness of 400 and $440 \mathrm{~m}$ for the Gravelly and Potter Valley depressions, respectively. Ground magnetic data indicate that the regional aeromagnetic data likely suffer from positional errors, but that large, long-wavelength anomalies, sourced from serpentinite, may be offset $8 \mathrm{~km}$ along the Bartlett Springs Fault zone. Additional gravity data collected either on the lake surface or bottom and in Potter Valley would better determine the shape of the basins. A modern, high-resolution aeromagnetic survey would greatly augment the ability to map and model the fault geometry quantitatively.

\section{Introduction}

In May of 2007, the U.S. Geological Survey (USGS) collected 153 new gravity stations, more than 37 line-kilometers of truck-towed magnetometer data, and more than 85 line-kilometers of boat-mounted magnetometer data in the Lake Pillsbury region of northern California, as part of an effort to characterize the Bartlett Springs Fault zone and the structure beneath Lake Pillsbury and Potter Valley, two intermontane valleys within the northern Coast Ranges (fig. 1). The Bartlett Springs Fault zone is part of the San Andreas Fault system and, along with the San Andreas and Maacama Fault zones, accommodates most of the right-lateral shear north of the San Francisco Bay area. Lake Pillsbury, located approximately $180 \mathrm{~km}$ north of San Francisco and $30 \mathrm{~km}$ east of Willits, is part of the Gravelly Valley pull-apart basin within the Bartlett Springs Fault zone. Potter Valley is an alluvial valley between the Bartlett Springs and the Maacama Fault zones and may be structurally controlled, although the amount of offset and the geometry of the bounding structures are poorly characterized.

A geophysical effort was begun to help determine basin geometry, infer structural features, and estimate depth to Pre-Cenozoic rocks, or basement in this region. Most of the study area consists of steep topography underlain by rocks of the Mesozoic Franciscan Complex, Great Valley Sequence, and serpentinized ultramafic rocks (fig. 2; Etter, 1979; Jennings and Strand, 1960). Significant Quaternary deposits in the region are limited to 
alluvium-filled basins at Potter and Gravelly Valleys; other Quaternary deposits including alluvium along the Eel River and large landslides that are particularly common along the Bartlett Springs fault zone are too thin to affect gravity measurements. The contrasts in density and magnetic properties among these rock types create measurable gravity and magnetic anomalies that can be modeled to determine the geometry of the source rock masses. Here we present gravity and magnetic maps based on new data, a compilation of aeromagnetic data for the area, and an inversion of the gravity data for thickness of Quaternary deposits.

\section{Acknowledgments}

We would like to thank Janet Tilden Watt and Daniel Scheirer for their review comments and suggestions. William D. Page (Pacific Gas and Electric Company; PG\&E) provided invaluable information on the latest Quaternary strands of the Bartlett Springs Fault zone and helped coordinate access to Lake Pillsbury. We thank T.K. Vaught and Michael Evans of PG\&E for their help with the PG\&E boat. This study was funded by the National Cooperative Geologic Mapping Program and by PG\&E.

\section{Gravity and Magnetic Data}

The gravity data in this report consist of 153 newly collected stations concentrated in the region of Lake Pillsbury and Potter Valley (fig. 3). The new measurements were along roads, except for 15 measurements made along the shore of Lake Pillsbury that were accessed by boat. These measurements were tied to primary base station CH66 at the Mendocino County courthouse in Ukiah at $39^{\circ} 09.02^{\prime} \mathrm{N}$ latitude and $123^{\circ} 12.44^{\prime} \mathrm{W}$ longitude (Chapman, 1966) with an observed gravity value of 980,018.55 milligals (mGal; value converted to IGSN71 datum). These data were combined with pre-existing gravity data (Chapman and others, 1975; Snyder and others, 1981).

More than 37 line-kilometers of truck-towed magnetometer data were collected along Forest Service roads to create a transect across the Lake Pillsbury area that is approximately perpendicular to the strike of the Bartlett Springs Fault zone. An additional 85 line-kilometers of magnetometer data were collected by boat on Lake Pillsbury, with 65 line-kilometers along 37 east-northeast-trending transects and 3 profiles along the arms of the lake (fig. 4). Truck-towed magnetic data were collected using a cesium vapor magnetometer attached to an aluminum carriage connected to the 
vehicle by aluminum tubing and towed about $9 \mathrm{~m}(30 \mathrm{ft})$ behind the vehicle. The sensor height was $3 \mathrm{~m}(9 \mathrm{ft})$. For boat operations, the magnetometer was mounted on a staff projecting forward of the bow of the boat and the Global Positioning System (GPS)

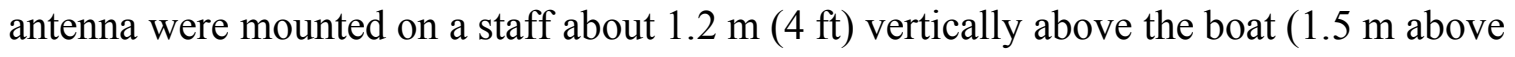
the lake surface). Magnetometer and GPS data were collected simultaneously at onesecond intervals, which at an average speed of $11 \mathrm{~km} / \mathrm{hr}(7 \mathrm{mph})$, corresponds to approximately one measurement every $3 \mathrm{~m}$ (10 ft). A centrally located portable protonprecession base station magnetometer was used to record diurnal variation of the Earth's magnetic field during the truck-towed and boat-mounted magnetometer surveys.

Regional aeromagnetic data were also compiled to produce an aeromagnetic map of the study area. Aeromagnetic data consist of several regional surveys flown at various altitudes, directions, and flightline spacings (table 1). Flightline spacing ranged from 800

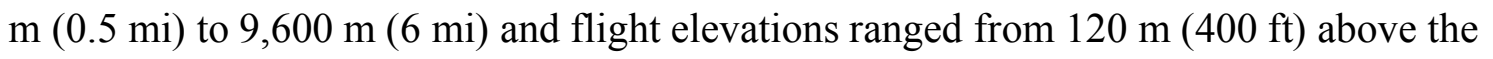
ground surface to $2134 \mathrm{~m}(7000 \mathrm{ft})$ constant altitude. The regional data were adjusted to a common datum and then merged by smooth interpolation across survey boundaries to produce an aeromagnetic map of the are (fig. 5; Roberts and Jachens, 1999). On Figure 5 we also show profile data for the entire area, collected as part of the National Uranium Resources Evaluation (NURE) project (Aero Service Corp., 1981). These data, collected in 1980, are probably better located than the older survey data (Brown and others, 1981; CDMG, 1978, unpublished) that covers the majority of the study area. These data are suitable for profile-based analysis, but not for robust map-based analysis, because these data were flown along lines too far apart $(9.6 \mathrm{~km} ; 6$ miles) to permit reliable construction of an aeromagnetic map.

Table 1. Aeromagnetic survey specifications

\begin{tabular}{lclcrl}
\hline Name & $\begin{array}{l}\text { Flightline } \\
\text { spacing (mi) }\end{array}$ & $\begin{array}{l}\text { Flightline } \\
\text { direction }\end{array}$ & $\begin{array}{c}\text { Altitude }^{1} \\
\text { (ft) }\end{array}$ & $\begin{array}{r}\text { Year } \\
\text { Flown }\end{array}$ & Reference \\
\hline Clear Lake & 0.5 & E-W & $1,000 \mathrm{AG}$ & 1985 & USGS 1988 \\
North Coastal & $0.5-1$ & NE-SW & $500 \mathrm{AG}$ & 1964 & CDMG 1978 \\
North Coastal SE & $0.5-1$ & NE-SW & $500 \mathrm{AG}$ & 1964 & unpublished \\
Stonyford & 1 & E-W & $7,000 \mathrm{~B}$ & 1962 & Brown \& others 1981 \\
Ukiah, CA & 6 & E-W & $400 \mathrm{AG}$ & 1980 & AeroService 1981
\end{tabular}

${ }^{1} \mathrm{~B}$, barometric (constant altitude above sea level); $\mathrm{AG}$, above ground 


\section{Gravity Methods}

All gravity data were reduced using standard gravity methods (Blakely, 1995) and include the following corrections: (a) earth-tide correction, which corrects for tidal effects of the moon and sun; (b) instrument drift correction, which compensates for drift in the instrument's spring; (c) latitude correction, which incorporates the variation of the Earth's gravity with latitude; (d) free-air correction, which accounts for the variation in gravity due to elevation relative to sea level; (e) Bouguer correction, which corrects for the attraction of material between the station and sea level; (f) curvature correction, which corrects the Bouguer correction for the effect of the Earth's curvature; (g) terrain correction, which removes the effect of topography to a radial distance of $167 \mathrm{~km}$ (104 mi); and (h) isostatic correction, which removes long-wavelength variations in the gravity field inversely related to topography.

Conversion of meter readings to gravity units was made using factory calibration constants as well as a secondary calibration factor determined by multiple gravity readings over the Mt. Hamilton calibration loop east of San Jose, California (Barnes and others, 1969). The gravity meters used in this survey, LaCoste and Romberg G614 and G17C, have secondary calibration factors of 1.00036 and 1.00078 respectively. Observed gravity values were based on a time-dependent linear drift between successive base readings and were referenced to the International Gravity Standardization Net 1971 gravity datum (Morelli, 1974, p. 18). Free-air gravity anomalies were calculated using the Geodetic Reference System 1967 formula for theoretical gravity on the ellipsoid (International Union of Geodesy and Geophysics, 1971, p. 60) and Swick's formula (Swick, 1942, p. 65) for the free-air correction. Bouguer, curvature, and terrain corrections were added to the freeair anomaly to determine the complete Bouguer anomaly at a standard reduction density of $2670 \mathrm{~kg} / \mathrm{m}^{3}$. Finally, a regional isostatic gravity field was removed from the Bouguer field assuming an Airy-Heiskanen model for isostatic compensation of topographic loads (Jachens and Roberts, 1981) with an assumed sea-level crustal thickness of $25 \mathrm{~km}$ (16 mi), a crustal density of $2670 \mathrm{~kg} / \mathrm{m}^{3}$, and a density contrast across the base of the model of 400 $\mathrm{kg} / \mathrm{m}^{3}$. Gravity values are expressed in $\mathrm{mGal}$, a unit of acceleration or gravitational force per mass equal to $10^{-5} \mathrm{~km} / \mathrm{s}^{2}$. Gravity data were gridded at an interval of $300 \mathrm{~m}$ using a computer program (Webring, 1981) based on a minimum curvature algorithm by Briggs (1974) and displayed as a color-contoured map (fig. 6).

Station locations and elevations were obtained with Trimble differential Global 
Positioning System (DGPS) using a GeoExplorer XT handheld receiver and an Ag132 pole-mounted receiver. The GeoExplorer XT receiver uses Wide Area Augmentation System (WAAS) correction messages, which combined with base station post-processing results in sub-meter vertical accuracy. The Ag132 receiver has real-time differential correction capabilities using an Omnistar satellite system, resulting in sub-meter horizontal accuracy and approximately 1-2 m (3-6 ft) vertical accuracy.

Terrain corrections, which account for the variation of topography near a gravity station, were computed using a combination of manual and digital methods. Terrain corrections consist of three parts: the innermost or field terrain correction, inner-zone terrain correction, and outer-zone terrain correction. Field terrain corrections were estimated in the field and extend from the station to a radial distance of $68 \mathrm{~m}(223 \mathrm{ft})$, equivalent to Hayford and Bowie (1912) zone B. Inner-zone terrain corrections were estimated from Digital Elevation Models (DEMs) with 10-m or 30-m resolutions derived from USGS 7.5' topographic maps and extend from $68 \mathrm{~m}(223 \mathrm{ft})$ to a radial distance of $590 \mathrm{~m}$ (1936 ft; D. Plouff, USGS, unpublished software, 2005). Outer-zone terrain corrections, calculated to a radial distance of $167 \mathrm{~km}$ (104 mi), were computed using a DEM derived from USGS 1:250,000-scale topographic maps (Plouff, 1966; Plouff, 1977; Godson and Plouff, 1988). Digital terrain corrections are calculated by computing the gravity effect of each grid cell using the distance and difference in elevation of each grid cell from the gravity station.

\section{Magnetic Methods}

During field operations, magnetic data were recorded at a sample rate of 1 second and viewed in real-time using Geometrics MagLog software. Raw magnetic data were downloaded and processed using MagMap2000 software, where magnetometer and GPS data were merged. The location of the magnetometer was recorded using the Trimble nonmagnetic Ag132 GPS receiver (described above) mounted on an aluminum frame attached to the magnetometer for the truck-towed data. Diurnal variations recorded by the centrallylocated base station magnetometer were removed from the dataset and the magnetic data were edited and filtered to remove cultural "noise" caused by passing cars, culverts, fences, and gates. Magnetic data were gridded and displayed as a color-contoured map (fig. 7). Data collected along road (fig. 8) required substantial editing and filtering because of cultural noise. 


\section{Physical Property Data}

Density and magnetic properties of rock samples are used for gravity and magnetic modeling, as well as gravity inversion calculations. The 14 rock samples were collected in the Lake Pillsbury-Potter Valley area (orange dots on figure 2) for rock property analyses. Densities were determined using a precision Sartorius electronic balance. All rocks were weighed dry in air (Wa), saturated in water (Ww), and saturated with water in air (Ws). From these measurements, grain density, dry bulk density, and saturated bulk density were calculated using the following formulas:

Grain density $=\mathrm{Wa} /(\mathrm{Wa}-\mathrm{Ws})$

Dry bulk density $=\mathrm{Wa} /(\mathrm{Ws}-\mathrm{Ww})$

Saturated bulk density $=\mathrm{Ws} /(\mathrm{Ws}-\mathrm{Ww})$

Magnetic susceptibilities were measured using a Geophysica KT-5 susceptibility meter and are reported to $0.01 \times 10^{-3} \mathrm{SI}$ units. The Geophysica KT-5 calculates volume susceptibility by assuming the sample shape is an infinite half-space. The instrument's ability to measure magnetic susceptibility is affected by surface roughness, weathering, and sample size, all of which can result in an underestimation of a sample's true susceptibility. The magnetic susceptibility values reported represent an average of multiple (4-8) readings on the sample. Magnetic susceptibility, along with density and rock identification are shown in table 2.

Table 2. Density and magnetic susceptibility data in $\mathrm{kg} / \mathrm{m}^{3}$ and $10^{-3}$ SI units

\begin{tabular}{|c|c|c|c|c|c|c|}
\hline Name Latitude & Longitude & $\begin{array}{r}\text { Grain } \\
\text { D }\end{array}$ & $\begin{array}{l}\text { Satu- } \\
\text { rated } \\
\mathrm{n} \mathrm{s} \mathrm{it}^{2}\end{array}$ & $\begin{array}{l}\text { Dry } \\
\text { Bulk } \\
\text { y }\end{array}$ & $\begin{array}{c}\text { Magnetic } \\
\text { Susceptibility }\end{array}$ & $\begin{array}{l}\text { Rock } \\
\text { Type }\end{array}$ \\
\hline SLIDE 39.4267 & -123.0163 & 2840 & 2780 & 2750 & 0.29 & Greenstone \\
\hline lp004a 39.4082 & -122.9623 & 2540 & 2520 & 2510 & 0.97 & Argillite \\
\hline lp004b 39.4082 & -122.9623 & 2240 & 2140 & 2060 & 32.0 & Serpentinite \\
\hline lp057r 39.4638 & -122.8928 & 2460 & 2420 & 2390 & 38.0 & Serpentinite \\
\hline lp059r 39.4750 & -122.8693 & 2640 & 2600 & 2580 & 0.24 & Sandstone \\
\hline lp061r 39.4832 & -122.8583 & 2550 & 2500 & 2470 & 53.0 & Serpentinite \\
\hline lp062r 39.4932 & -122.8602 & 2690 & 2680 & 2670 & 0.19 & Meta-graywacke \\
\hline lp081 39.4768 & -122.9243 & 2660 & 2590 & 2550 & 0.18 & Graywacke \\
\hline 39.4985 & -122.9332 & 2700 & 2690 & 2680 & 0.11 & Chert \\
\hline 39.3990 & -123.0320 & 2690 & 2650 & 2630 & 0.15 & Graywacke \\
\hline lp111 39.3182 & -123.0675 & 2570 & 2460 & 2390 & 0.12 & Graywacke \\
\hline lp112r 39.3092 & -123.0780 & 2560 & 2470 & 2410 & 37.0 & Serpentinite \\
\hline lp114r 39.3215 & -123.0938 & 2930 & 2920 & 2920 & 0.60 & Blueschist \\
\hline lp114r 39.3215 & -123.0938 & 2380 & 2250 & 2160 & 18.8 & Serpentinite \\
\hline
\end{tabular}




\section{Gravity Anomalies and Depth to Basement}

In general, isostatic gravity anomalies reflect lateral (horizontal) density variations in the middle to upper crust. Thus, gravity anomalies can be used to infer the subsurface structure of known or unknown geologic features. Gravity anomalies often reveal features such as basement terranes, sedimentary basins, and faults. In the Lake Pillsbury region, substantial gravity variations occur over exposed Mesozoic basement, with gravity highs southwest of Lake Pillsbury and in the Snow Mountain area and gravity lows generally to the northeast of Lake Pillsbury. Along a 30-km-long stretch, the Bartlett Springs fault zone lies at the base of a significant, northwest-striking gravity gradient of 15-20 mGal. Superposed on the gravity variations caused by density variations in the Mesozoic basement are smaller gravity lows over Lake Pillsbury and Potter Valley that have an amplitude of 6-8 mGal. For an infinite horizontal slab with a density contrast $\Delta \rho$ (in $\mathrm{kg} / \mathrm{m}^{3}$ ), and thickness $\mathrm{L}$ (in meters), the resulting gravity anomaly, $\Delta \mathrm{g}$, is given as:

$$
\Delta \mathrm{g}=0.000041896 \Delta \rho \mathrm{L}
$$

Reasonable density contrasts between Mesozoic basement rocks and lower-density Quaternary deposits range from 400 to $600 \mathrm{~g} / \mathrm{cm}^{3}$, thus, the thickness of Quaternary fill beneath Lake Pillsbury and Potter Valley is, to first order, about 240-480 m.

A more sophisticated method to estimate the thickness of Quaternary fill uses a 3dimensional iterative technique (Jachens and Moring, 1990) that separates the gravity anomaly into a component caused by variations in thickness of the Quaternary deposits and a component caused by density variations in the basement rocks. The method requires knowledge of the gravity field, exposed geology, and vertical density variation within the Cenozoic basin deposits. This method does not take into account lateral variations in the density distribution of the Quaternary deposits. Gravity data are separated into observations made on bedrock outcrops and observations made over the basin. A first approximation of the bedrock gravity field is determined by interpolating a smooth surface through all gravity values measured on bedrock outcrops. The basin gravity is then the difference between the observed gravity field on the original map and the first approximation of the bedrock gravity field and is used to calculate the first approximation of the thickness of Cenozoic deposits. The thickness is forced to zero where bedrock is exposed. This first approximation of the bedrock gravity is too low near the basin edges because of the effects of the nearby low-density deposits on the bedrock stations. The 
bedrock gravity station values are "corrected" for the effects of the low-density deposits (the effects are calculated directly from the first approximation of the thickness of the Cenozoic deposits) and a second approximation of the bedrock gravity field is made by interpolating a smooth surface through the corrected bedrock gravity observations. This iteration leads to an improved estimate of the basin gravity field, an improved depth to bedrock and a new correction to the bedrock gravity values. This procedure is repeated until successive iterations produce no significant changes in the bedrock gravity field.

This method can use well data or other independent picks on the thickness of the Quaternary deposits to constrain the inversion; however, none was available for constructing the basin model shown in figure 9. Given the lack of information on the density of the Quaternary deposits and whether it varies with depth, we assumed a density contrast of $400 \mathrm{~kg} / \mathrm{m}^{3}$ between the basement and the basin fill. This density contrast most likely provides an estimate of the maximum thickness; more likely the density contrast is higher and the thickness is less. The basin thickness results indicate a maximum thickness of 400 and 440 meters beneath the Lake Pillsbury depression and Potter Valley, respectively (fig. 9). The deepest part of the basin beneath Lake Pillsbury is in the northern part of Gravelly Valley, although there are no gravity measurements within the lake to constrain the inversion. The thickest basin fill is in the southern part of Potter Valley.

\section{Magnetic Anomalies}

Magnetic anomalies reflect lateral variations in the magnetization of rocks. These anomalies can be explained by the variations in rock type across the region. In the northern Coast Ranges, aeromagnetic anomalies generally reflect Mesozoic basement rock types (ophiolitic rocks including serpentinite, gabbro and basalt) either exposed or in the subsurface (see for example, Griscom and Brown in Brown and others, 1981). The prominent aeromagnetic anomaly that strikes northwest across Lake Pillsbury (fig. 5) coincides with a narrow belt of serpentinite outcrops localized along the Bartlett Springs Fault zone (fig. 2). Aeromagnetic anomalies also coincide with serpentinite outcrops in the northwest corner of our study area, along the northern margin of the volcanic rocks of the Franciscan Complex in the Snow Mountain wilderness, and 5-10 km north of Potter Valley.

The NURE and ground magnetic data suggest that there may be positioning errors in the older regional data collected in the 1960s. For example, the NURE and regional 
aeromagnetic data show a magnetic high that is bounded by strands of the Bartlett Springs fault zone south of Lake Pillsbury (fig. 5). The position of the apex of the high on the NURE data, however, is more than $1 \mathrm{~km}$ east of the apex of the high shown in the regional magnetic map. At the west end of truck-towed profile A-A', regional data indicate a sharp gradient that is not seen in the truck-towed data (fig. 8); the NURE data suggest that the steep gradient is $1 \mathrm{~km}$ west of where it is shown in the regional date (fig. 5). These positioning errors highlight the limited utility of the regional data. Although the regional data clearly show large, long-wavelength aeromagnetic anomalies, one cannot model these data quantitatively for fault dip and location, or serpentinite geometry.

Despite the limitations of the regional data, we examined these data to estimate cumulative offset on the Bartlett Springs Fault zone by matching magnetic anomalies across the fault. We speculatively correlated two pairs of anomalies (a-a' and b-b' fig. 5) that indicate about $8 \mathrm{~km}$ of apparent right-lateral displacement.

The boat-mounted magnetic data show a positive anomaly that bisects Lake Pillsbury (north-to-south), which is more or less consistent with the regional aeromagnetic data, although the position of the prominent low east of McLeod Ridge does not match the location of the low from the aeromagnetic data. Unfortunately, the southeast arm of the lake does not extend far enough west to fully characterize the magnetic low. The axis of the lake anomaly coincides with one of the late Quaternary strands of the Bartlett Springs Fault zone (PG\&E Geosciences Department, 2006), which is a strike-slip fault trenched by Geomatrix Consultants (1986). The eastern edge of another magnetic high imaged on the easternmost part of truck-towed line B-B' and on the southwestern part of the lake survey coincides with lineaments mapped by Geomatrix Consultants (1986) and likely coincides with the western fault bounding the Gravelly Valley pull-apart basin. The eastern margin of a subtle magnetic high in the northeast corner of the lake and on truck-towed profile AA' coincides with the easternmost lineament and strand of the Bartlett Springs Fault zone, most likely the eastern fault bounding the Gravelly Valley pull-apart basin.

\section{Recommendations}

The basin inversion results could be improved by utilizing density information, well constraints and additional gravity data. The basin inversion results for Lake Pillsbury would be enhanced with additional gravity data within the lake itself. These data could be lake-bottom measurements given the relative shallow depth of the lake (less than $30 \mathrm{~m}$ ) or 
could be collected by boat on the lake surface. An uncertainty in the gravity measurement of $0.5 \mathrm{mGal}$ would lead to an uncertainty of 20-30 $\mathrm{m}$ in basin thickness. Additional gravity data along the western margin of Potter Valley would improve the separation of the gravity field into the basement and basin components and most likely would reduce the steep southwestern basin edge (fig. 9).

The regional and new ground magnetic data, despite limitations in resolution and areal extent, show the utility of magnetic data to map strands of the Bartlett Springs fault zone and to provide possible constraints on cumulative fault offset. A modern, highresolution aeromagnetic survey would greatly augment the ability to map and model the fault geometry quantitatively.

\section{Conclusions}

New gravity data provide constraints on basin geometry beneath Lake Pillsbury and Potter Valley, suggesting maximum basin depths of about 400 and $440 \mathrm{~m}$, respectively. The basin fill may as thin as $\sim 200 \mathrm{~m}$. Significant gravity variations arise from density contrasts within the Mesozoic basement, with high values southwest of Lake Pillsbury and low values to the northeast.

New magnetic data show a linear magnetic anomaly that bisects Lake Pillsbury. The edges of the source body correspond in part with mapped and inferred traces of the Bartlett Springs Fault zone. The new data also highlight possible positioning errors in the regional aeromagnetic data that cover this region. In spite of the limited resolution and probable positioning errors of the regional data, we speculate the amount of apparent rightlateral displacement on the Bartlett Springs Fault zone to be about $8 \mathrm{~km}$. A high-resolution aeromagnetic survey would provide detailed data over a large areal extent in a timely fashion, covering areas where ground magnetic data collection is limited by road access and cultural noise. Such data coverage would allow more comprehensive mapping and modeling of the fault zone.

\section{References Cited}

Aero Service Corp, 1981, Airborne gamma-ray spectrometer and magnetometer survey Ukiah Quadrangle: U.S. Department of Energy, Grand Junction Office Report GJBX-390(81), 2 vols.

Barnes, D.F., Oliver, H.W., and Robbins, S.L., 1969, Standardization of gravimeter calibrations in the Geological Survey: Eos, Transactions, American Geophysical Union, v. 50, no. 10, p. 626-627. 
Blakely, R.J., 1995, Potential Theory in Gravity and Magnetic Applications, Cambridge University Press, New York.

Briggs, I.C., 1974, Machine contouring using minimum curvature: Geophysics, v. 39, p. 39-48.

Brown, R.D., Jr., Grimes, D.J., and Leinz, Reinhard, 1981, Mineral Resources of the Snow Mountain Wilderness Study area, California, with a section on Interpretation of aeromagnetic data by Andrew Griscom and R.D. Brown, Jr.: U.S. Geological Survey Bulletin 1495, 48 p., scale 1:62,500.

California Division of Mines and Geology (CDMG), 1978, Aeromagnetic maps of the north coastal area, California: California Division of Mines and Geology Open-File Report 78-11E, 11 sheets, scale 1:62.500.

Chapman, R.H., 1966, Gravity base station network: California Division of Mines and Geology Special Report 90, 49 p.

Chapman, R.H., Bishop, C.C., Chase, G.W., and Gasch, J.W., 1975, Bouguer gravity map of California, Ukiah sheet: California Division of Mines and Geology Map, scale $1: 250,000$.

Etter, S.D., 1979, Geology of the Lake Pillsbury area, northern Coast Ranges, California: University of Texas at Austin doctorate thesis, $275 \mathrm{p}$.

Geomatrix Consultants, 1986, Geological assessment of the seismic potential of the Bartlett Springs shear zone for Scott Dam, Lake County, California: Final report by Geomatrix consultants (Taylor, C.L., and Swan, F.H.) for Pacific Gas and Electric Company, $51 \mathrm{p}+$ figures.

Godson, R.H., and Plouff, Donald, 1988, BOUGUER version 1.0, a microcomputer gravity-terrain-correction program: U.S. Geological Survey Open-File Report 88644-A, Documentation, 22 p.; 88-644-B, Tables, 61 p., 88-644-C, 5 1/4 - in diskette.

Hayford, J.F., and Bowie, William, 1912, The effect of topography and isostatic compensation upon the intensity of gravity: U.S. Coast and Geodetic Survey Special Publication no. 10, $132 \mathrm{p}$.

International Union of Geodesy and Geophysics, 1971, Geodetic Reference System 1967: International Association of Geodesy Special Publication no. 3, 116 p.

Jachens, R.C., and Moring, B.C., 1990, Maps of the thickness of Cenozoic deposits and the isostatic gravity over basement for Nevada: U.S. Geological Survey Open-File Report 90-404, 15 p.

Jachens, R.C., and Roberts, C.W., 1981, Documentation of a FORTRAN program, 'isocomp', for computing isostatic residual gravity: U.S. Geological Open-File Report 81-574, 26 p.

Jennings, C.W., and Strand, R.G., 1960, Geologic map of California, Ukiah sheet: California Division of Mines and Geology, scale 1:250,000.

Jennings, C.W., 1994, Fault activity map of California: California Division of Mines and Geology Data Map 6, scale 1:750,000.

Langel, R.A., 1992, International geomagnetic reference field: the sixth generation: Journal of Geomagnetism and Geoelectricity, v.44, no. 9, p. 679-707.

Morelli, C., ed, 1974, The International Gravity Standardization Net 1971: International Association of Geodesy Special Publication no. 4, 194 p.

PG\&E Geosciences Department, 2006, Regional geology and seismicity in the Scott Dam region, Lake County, California: report prepared for Hydro Engineering Department, Pacific Gas and Electric Co., 79 p.

Plouff, Donald, 1966, Digital terrain corrections based on geographic coordinates [abs.]: 
Geophysics, v. 31, no. 6, p. 1208.

Plouff, Donald, 1977, Preliminary documentation for a FORTRAN program to compute gravity terrain corrections based on topography digitized on a geographic grid: U.S. Geological Survey Open-File Report 77-535, 45 p.

Roberts, C.W., and Jachens, R.C., 1999, Preliminary aeromagnetic anomaly map of California: U.S. Geological Survey Open-File Report 99-440, 14 p.

Snyder, D.B., Roberts, C.W., Saltus, R.W., and Sikora, R.F., 1981, Magnetic tape containing the principal facts of 64,402 gravity stations in the State of California: U.S. Geological Survey Report, 30 p.; available from National Technical Information Service, U.S. Department of Commerce, Springfield, Virginia 22161, PB82-168287.

Swick, C.A., 1942, Pendulum gravity measurements and isostatic reductions: U.S. Coast and Geodetic Survey Special Publication 232, 82 p.

U.S. Geological Survey, 1988, Aeromagnetic map of the northern Clear Lake area, Lake and Colusa counties, California: U.S. Geological Survey Open-File Report 88-507, scale 1:62,500.

Waldhauser, Felix, and W.L. Ellsworth (2000). A double-difference earthquake location algorithm; method and application to the northern Hayward Fault, California: Bull. Seismo. Soc. Am. 90, p. 1353-1368.

Webring, M.W., 1981, MINC-A gridding program based on minimum curvature: U.S. Geological Survey Open File Report 81-1224, 43 p. 


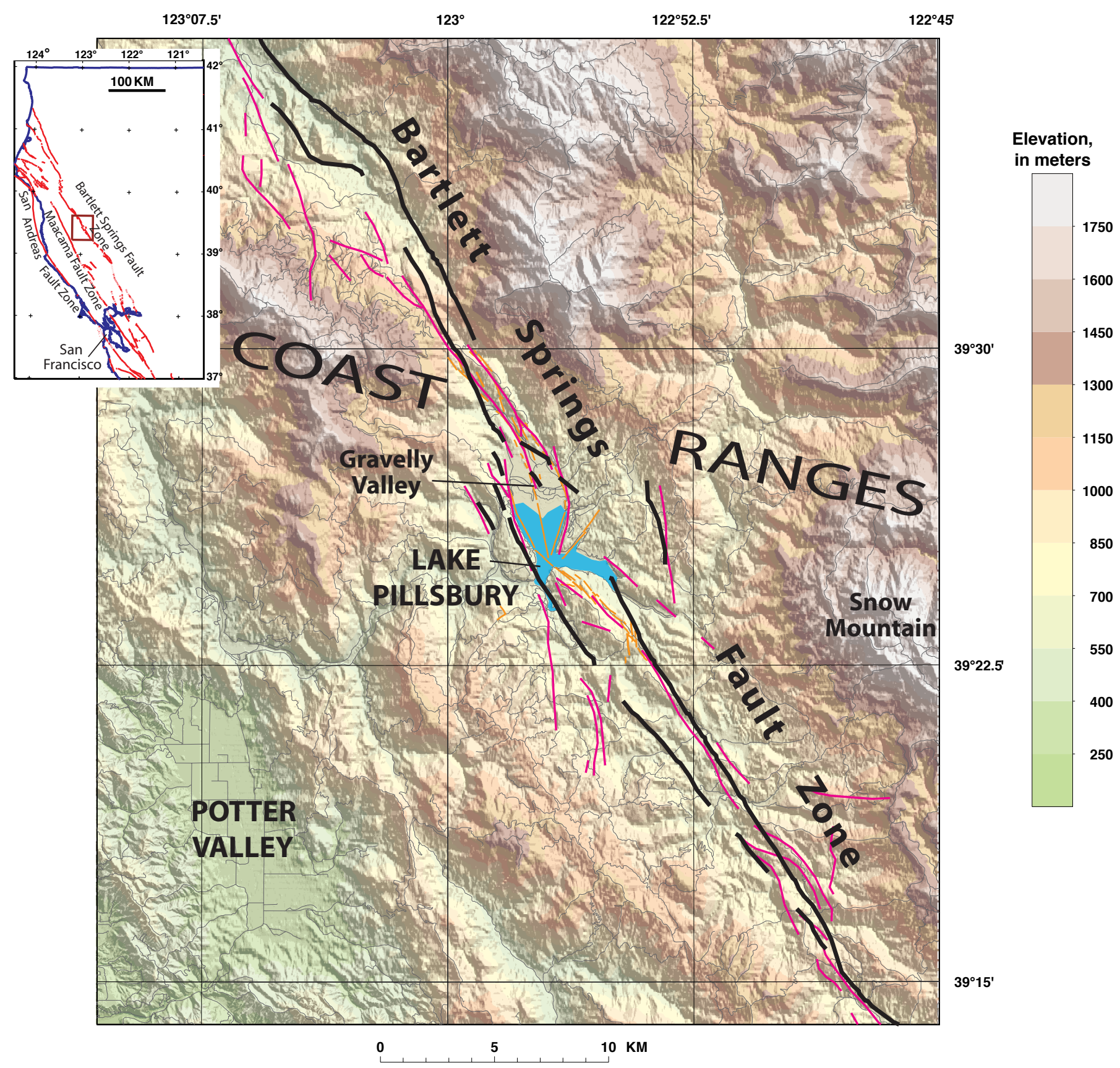

Fig. 1. Index map of study area. Black lines, Bartlett Springs Fault zone from Jennings (1994), magenta lines, lineaments from Geomatrix (1986), orange lines, late Quaternary faults from PG\&E Geosciences Department (2006), and gray lines, roads and trails. 


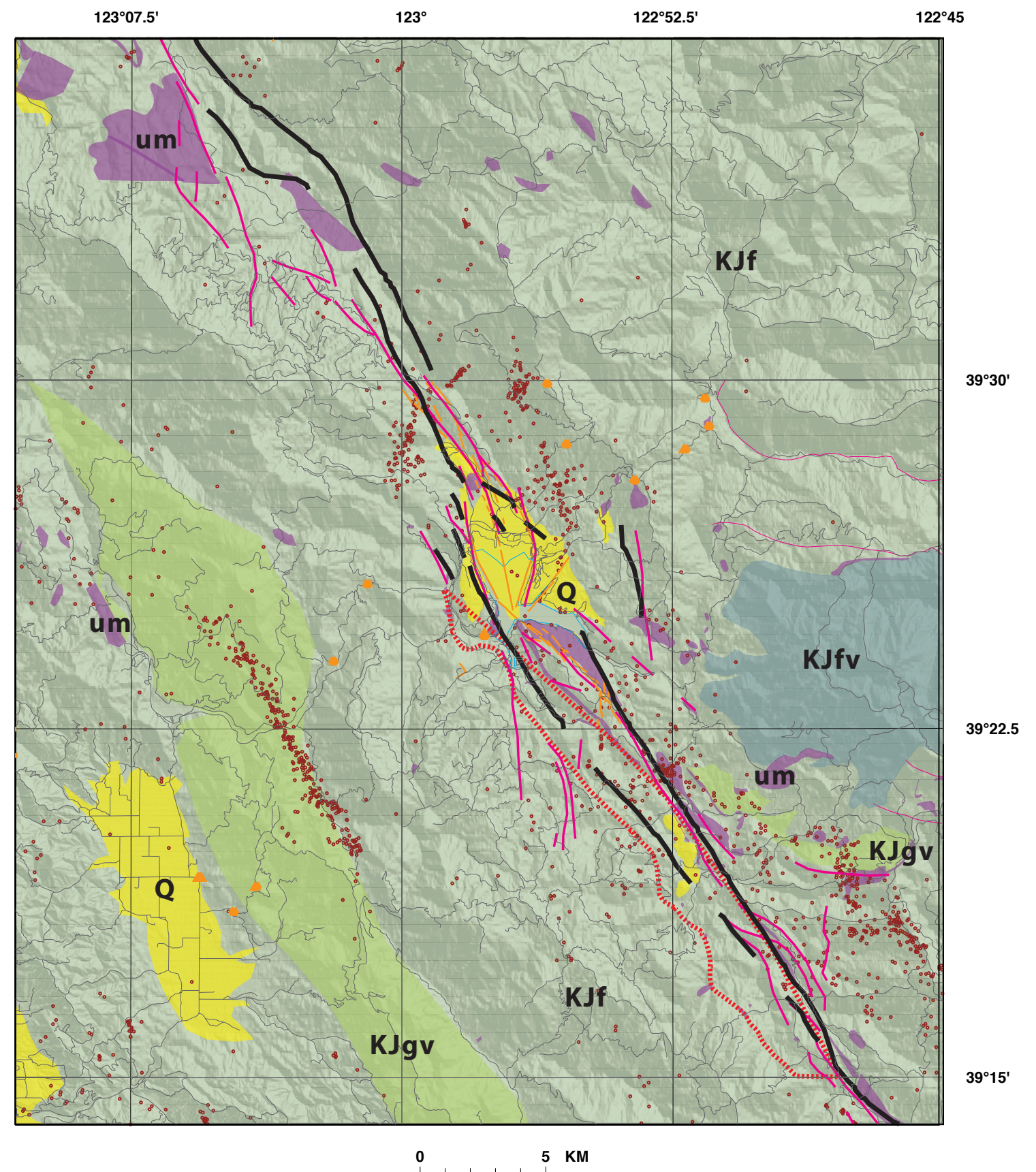

Figure 2. Simplified geologic map of study area (modified from Etter, 1979; Jennings and Strand, 1960). Q, Quaternary deposits; KJf, undifferentiated Franciscan Complex; KJfv, volcanic rocks of the Franciscan Complex, KJgv, Great Valley Sequence; um, ultramafic rocks and serpentinite. Faults and roads fron figure 1. Red dotted line denotes Hot Springs shear zone (from Etter, 1979). Brown dots, seismicity located by double-difference method (Waldhauser and Ellsworth, 2000). Orange dots, physical property sample locations. 


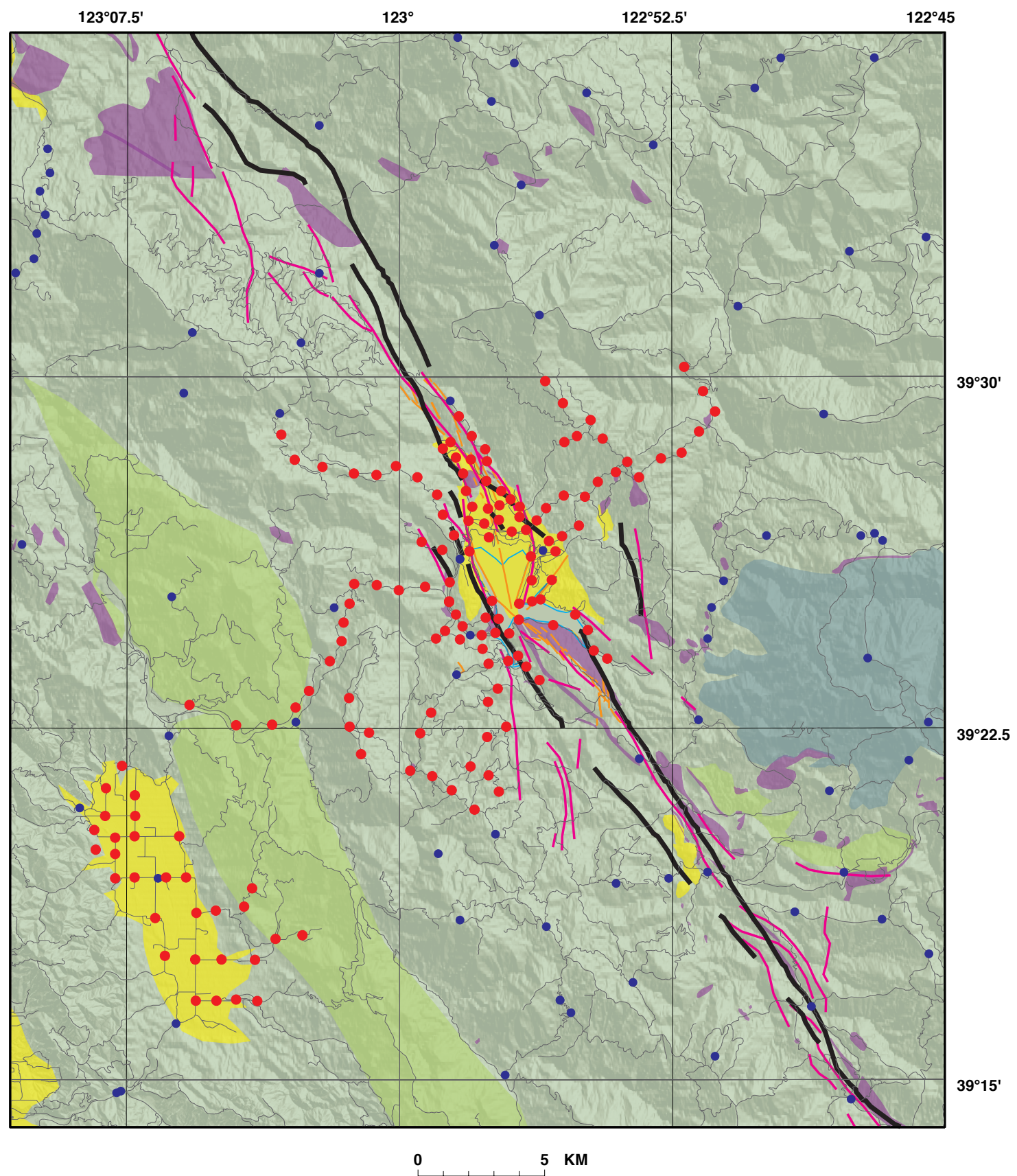

Figure 3. Map of gravity measurements. Red circles, new data; dark blue circles, pre-existing data. See figure 2 for explanation of geology. Faults and roads from figure 1. 


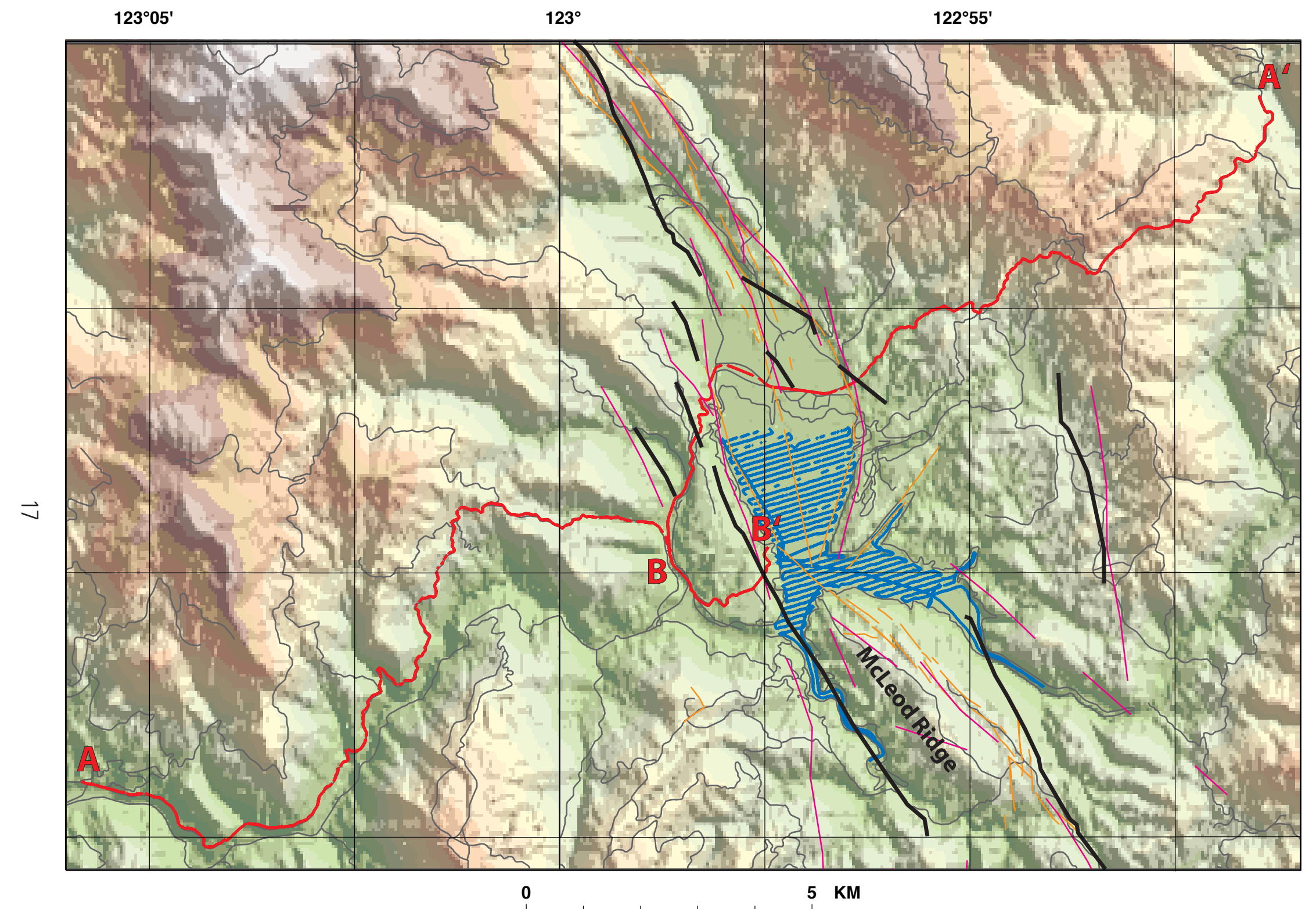

Figure 4. Locations of truck-towed and boat-mounted magnetic data, red and blue lines, respectively. A-A' and B-B' are profile endpoints shown in figure 8. Faults and roads same as in figure 1. 


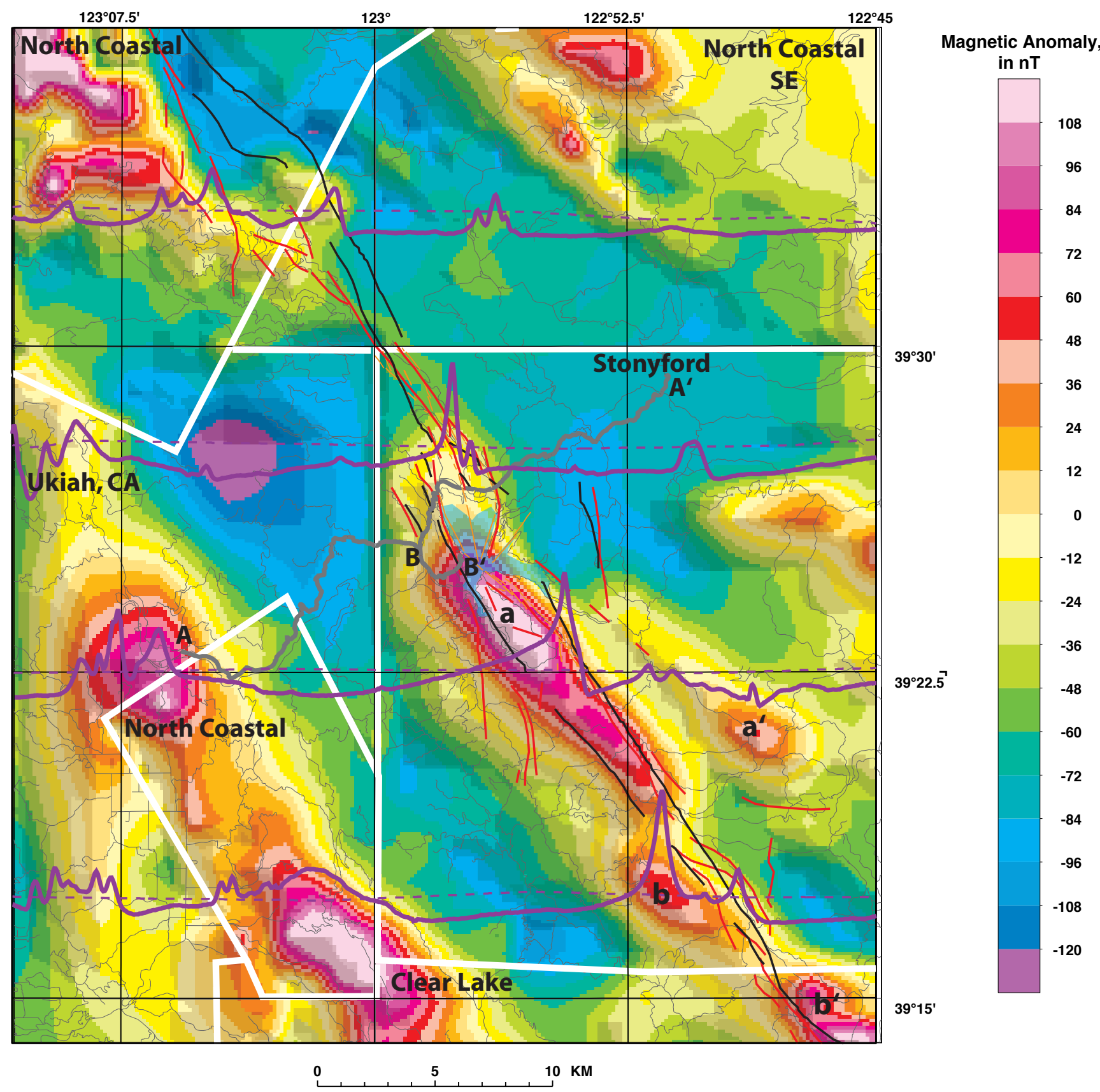

Figure 5. Aeromagnetic map of study area. White lines show survey boundaries. See table 1 for survey specifications. Purple lines are magnetic field variations along the NURE (Ukiah, CA) profiles; dotted purple lines show NURE flight lines. Maximum amplitude of anomaly in NURE data is about $500 \mathrm{nT}$. Heavy gray lines show location of truck-towed ground magnetic profiles A-A' and B-B'. Semitransparent blue polygon is Lake Pillsbury. Anomalies $a, a^{\prime}, b$, and b' are discussed in text. 


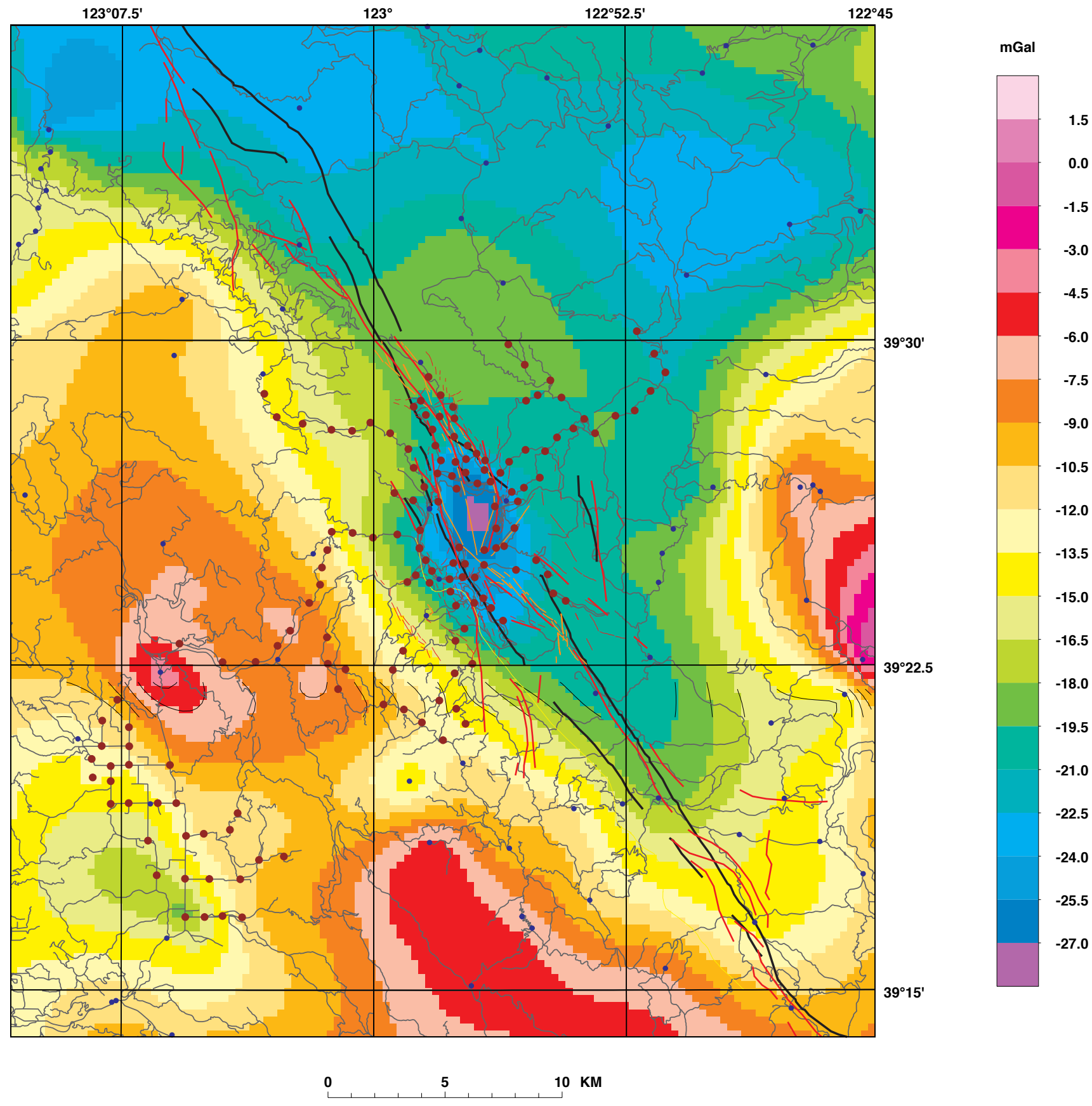

Figure 6. Isostatic gravity map. Faults and roads same as in figure 1. Brown circles, new data; dark blue dots, pre-existing data. 


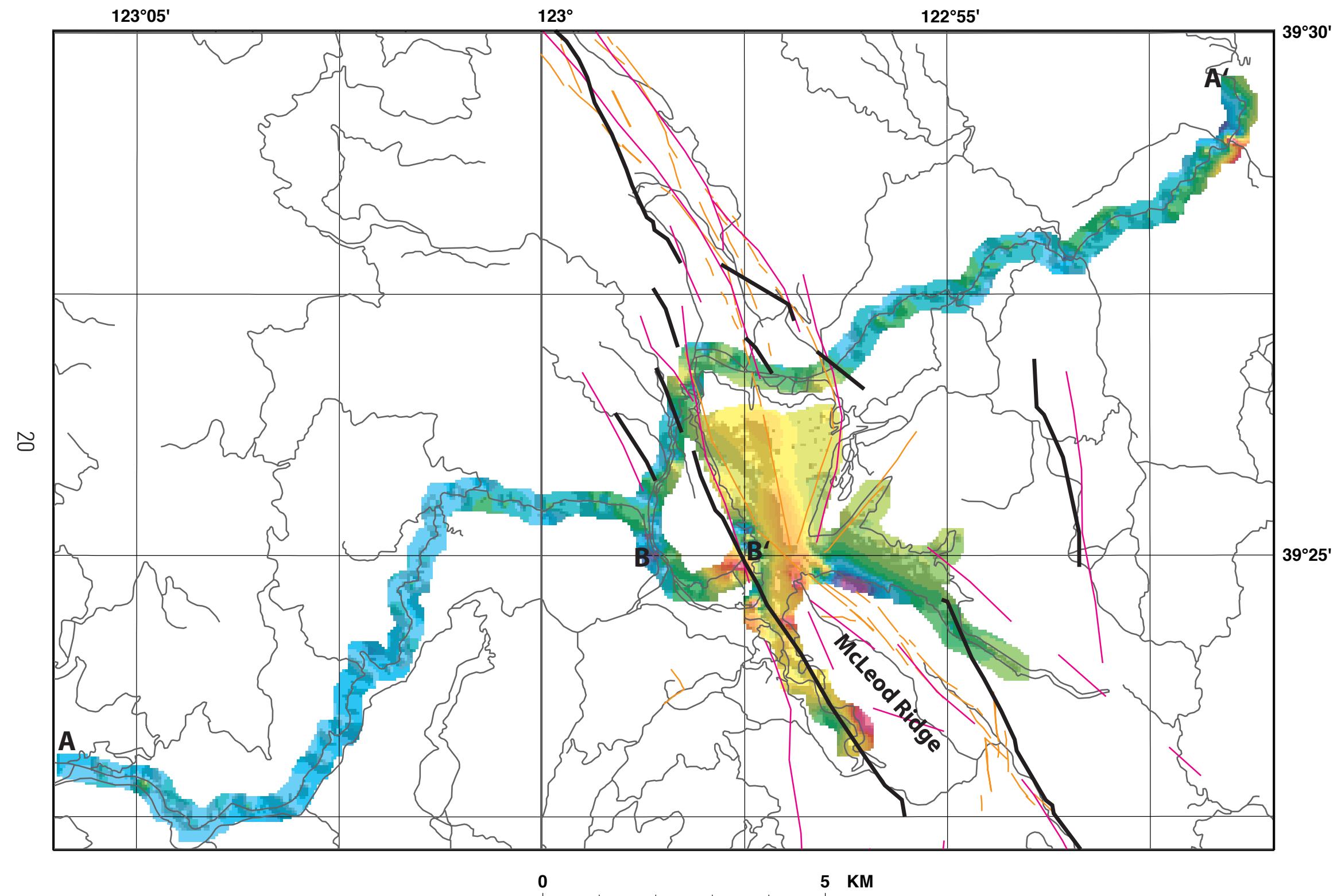

Figure 7. Shaded-relief magnetic map of truck-towed and boat-mounted magnetic data. Sun angle is from the northeast. Faults and roads same as in figure 1 . 

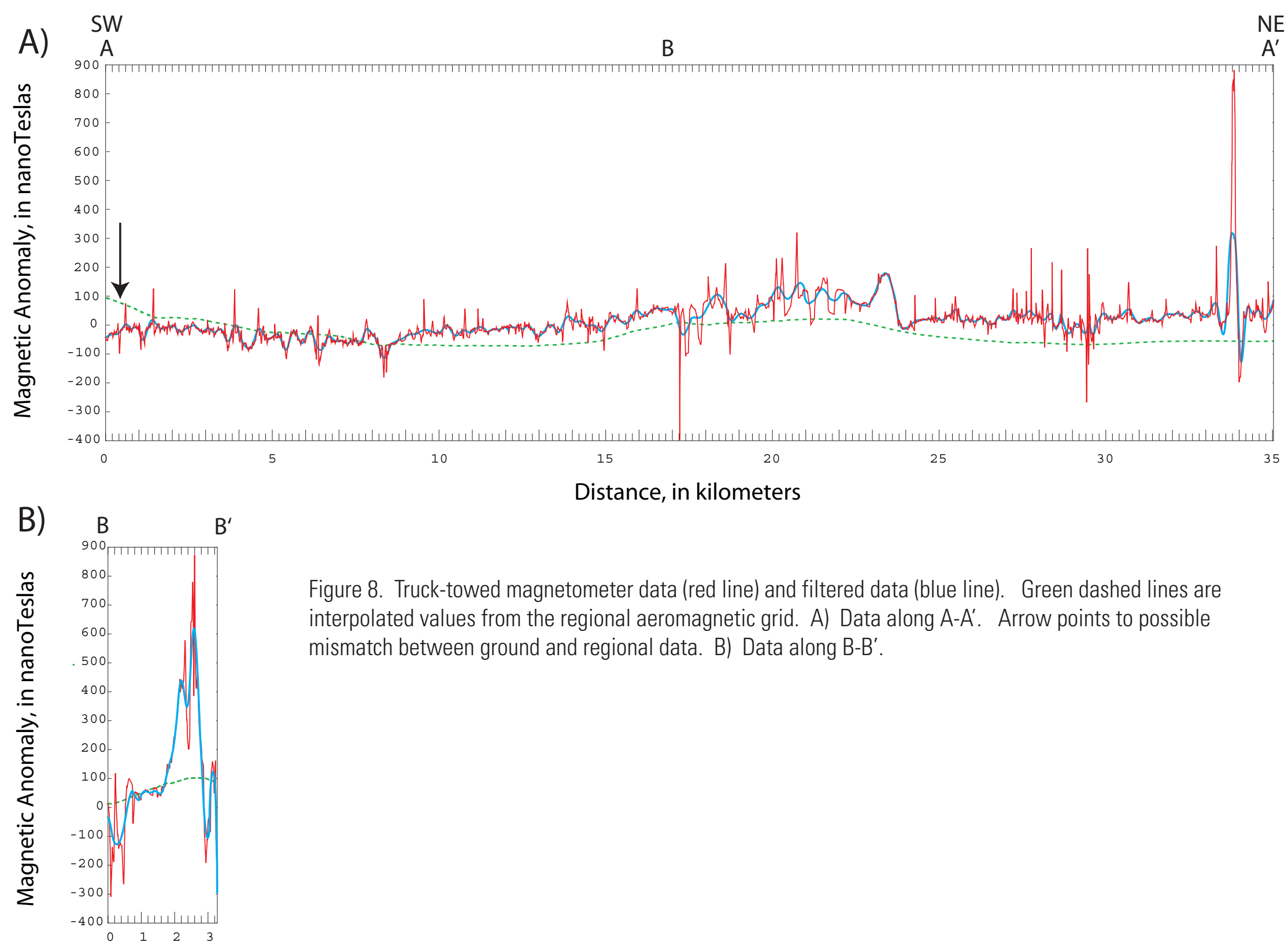

Distance, in kilometers

Figure 8. Truck-towed magnetometer data (red line) and filtered data (blue line). Green dashed lines are interpolated values from the regional aeromagnetic grid. A) Data along A-A'. Arrow points to possible mismatch between ground and regional data. B) Data along B-B'.

\section{Distance, in kilometers}




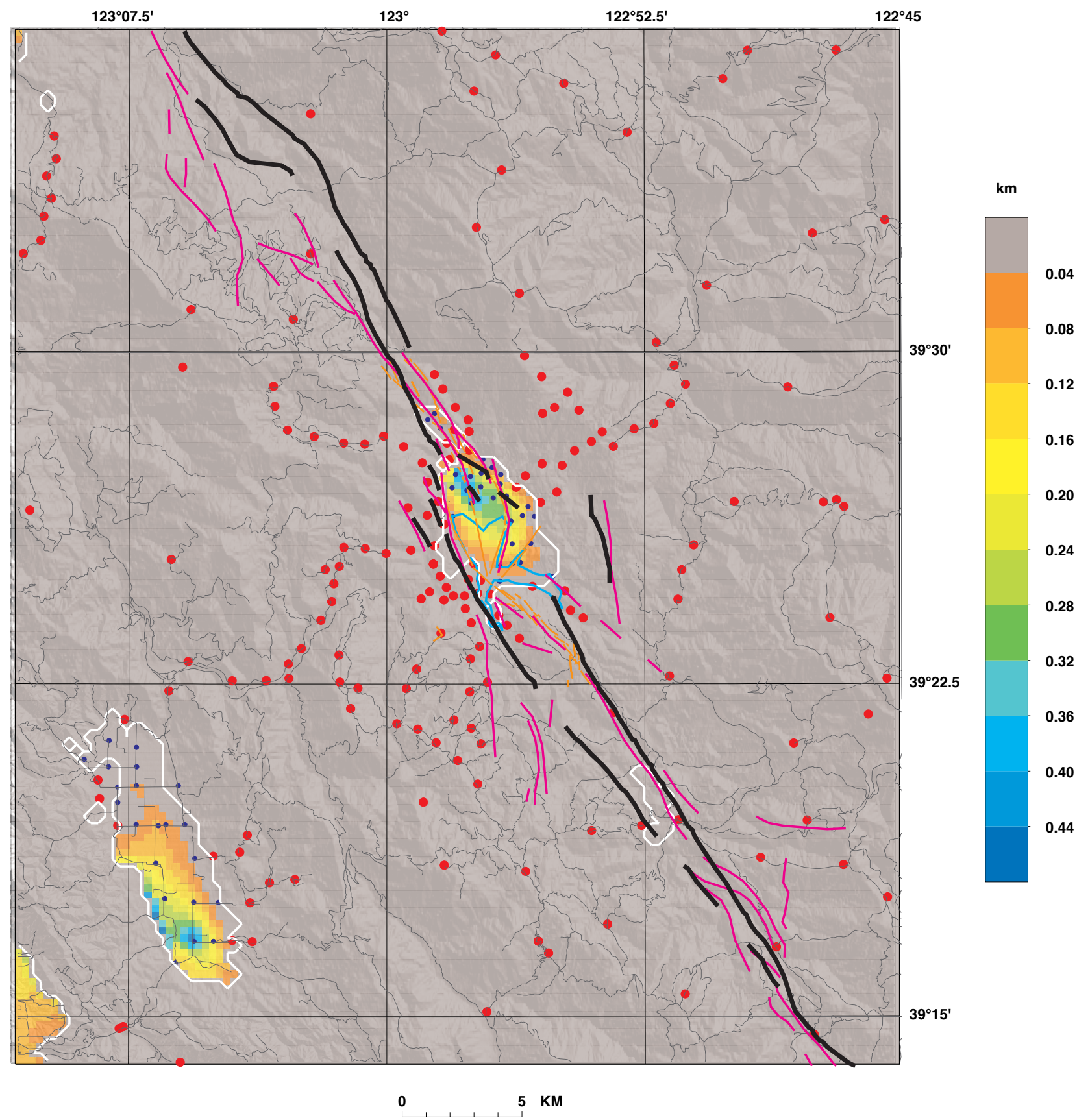

Figure 9. Thickness of Quaternary deposits from inversion of gravity data. Control points for the inversion include gravity measurements made on basement (red circles), and the basement contact (white line). Dark blue dots are gravity measurements made on Quaternary deposits. Blue line shows extent of Lake Pillsbury. 